\title{
Investigating land surface deformation using InSAR and GIS techniques in Cluj-Napoca city's most affected sector by urban sprawl (Romania)
}

\author{
Anna-Hajnalka KEREKES ${ }^{1 *}$, Szilárd Lehel POSZET², Călin BACIU1 \\ ${ }^{1}$ Faculty of Environmental Science and Engineering, Babeș-Bolyai University, Cluj-Napoca, Romania \\ ${ }^{2}$ Sapientia Hungarian University of Transylvania, Faculty of Sciences and Arts, Department of Environ- \\ mental Sciences, Cluj-Napoca, Romania
}

Received 30 September 2020; Revised 20 November 2020; Accepted 23 November 2020

*Correspondence to: Anna-Hajnalka KEREKES; e-mail: annakrks@yahoo.com

\begin{abstract}
The last three decades have marked an unprecedented urban expansion of the city of Cluj-Napoca, leading to strong anthropogenic influences on the natural environment and important changes in the land-use. Due to the specific morphology of Cluj area, characterized by restrained plane surfaces, which are insufficient to support the urban expansion, more and more territories with slopes between $5^{\circ}-26^{\circ}$ are used for constructions. These areas are marked by high risks of mass movements due to their specific geological and geomorphological characteristics, therefore the present study proposes a more detailed and complex GIS and remote sensing analysis of ClujNapoca's most affected area by urban sprawl, in order to highlight the main changes of the city and the consequences of the human actions. One of the most used radar interferometry techniques (InSAR) was applied to detect land deformations that can threaten the infrastructure and the population. Sentinel-1B SAR imagery was processed by DInSAR methodology, resulting in a land surface deformation map, which represents an important support in generating a predisposition assessment. Based upon this evaluation, we concluded that the most predisposed neighbourhoods (from the study area) to active land deformations are the peripheral ones, as following: Dâmbul Rotund, Bună Ziua, Europa, Mănăștur, West Iris and Făget, proving that human activity and the geological setting are the main triggering factors of the discussed phenomenon.
\end{abstract}

KEYWORDS GIS, remote sensing, Cluj-Napoca, land surface deformation, urban planning, InSAR, DInSAR

\section{Introduction}

Mass movement or mass wasting represents the displacement of materials (snow, ice, soil, debris, rock) under the force of gravity, in downhill or downward direction, inducing land surface deformations (natural or anthropic hazards), like land- 
sliding, subsidence, soil creeping, rockfalls, mudflows, debris flows and avalanches (Coleman and Prior, 1988; Griffiths, 2018; Chen et al., 2019). These processes can cause severe social and economic damages, therefore monitoring, mapping land surface deformations with different up-to-date Earth Observation methods and technologies becomes essential. Producing vulnerability, susceptibility and predisposition frameworks are fundamental to reduce the impact of damage (Sun et al., 2015), thus helping the improvement of urban planning for future expansion strategies.

In the past decades, many studies and investigations used remote sensing techniques in order to examine and investigate mass movement processes, revealing spatial and temporal information and data. The InSAR satellite-based technique (Interferometric Synthetic Aperture Radar) is a widespread method to measure mass movements and displacements of the Earth's surface, with millimetric accuracy (Fiaschi et al., 2017; Wempen, 2020). Gabriel et al. (1989) were the first researchers that rendered the theoretical approach of InSAR and successfully generated a map with small elevation changes. Based upon their research, Massonnet was the first who applied this technique to detect ground motion (Massonnet et al., 1993; Massonnet et al., 1995). The technology was widely and efficiently used in the past years to quantify geological hazards, like volcanic and seismic activity (Peltier et al., 2010; Antonielli et. al., 2014; Chini et al., 2015) and different types of land displacements, like subsidence, debris flow, soil-creeping and landslides (Carnec et al., 1996; Galloway et al. 1998; Cascini et al., 2010; Abidin et al., 2013; Heckmann et al., 2014; Calò et al., 2014; Solari et al., 2016). Moreover, due to constant development in precision and accuracy of satellite imagery and remote sensing techniques, the InSAR method became more efficient, budgetand time-friendly (in comparison to the classical methods) to generate multitemporal measurements of large sections of areas (Cascini et al., 2010; Ullo et al., 2019). Numerous studies successfully used SAR with GIS techniques to investigate and map vulnerable urban areas to different types of terrain displacements caused by geohazards, like landsliding, subsidence and volcanic activity, taking into account social and economic dimensions (Béjar-Pizarro et al., 2017; Solari et al., 2018; Ezquerro et al., 2020). In these studies, infrastructure damages were effectively approximated and vulnerable buildings maps were generated. Susceptibility frameworks were also produced by using radar technology, predicting highly prone areas to different mass movement types based on multiple environmental factors (Zhao et al., 2019; Bianchini et al., 2019; Jiaxuan et al., 2020).

The interferometrical SAR techniques can be grouped into two different classes: DInSAR (Differential InSAR) and PSI (Persistent Scatterers Interferometry) method. The PSI technique was created because DInSAR is only capable of measuring the differences and shifts between two points (two images) in time, it does not possess the ability to differentiate the linear motion from the nonlinear one, and it also has its limitations caused by atmospheric or signal disturbances and changes in reflections of objects (Oštir and Komac, 2007; Fiaschi et al., 2017). Therefore, the PSI approach is able to overcome the above-mentioned limitations by using highly correlated dominating scatters (Sun et al., 2015) and can also be grouped into two main classes: PSInSAR (Permanent Scatterers InSAR) and Small Baseline Subset (SBAS). PSInSAR is capable to determine, over a longer period, coherent radar targets (Oštir and Komac, 2007), whereas SBAS measures the displacements of distributed scatterers by combining radar images with small baselines (Fiaschi et al., 2017), moreover, these methods were successfully used by Ferretti et al., 2001; Lanari et al., 2004; Lauknes, 2010; Solari et al., 2016; Ma et al., 2016; Solari et al., 2018).

The DInSAR technique can be suitably applied on large areas to measure surface displacements, offers a quick look of their apportionment, generates continuous data and detects slow deformations (Oštir and Komac, 2007; Dalla Via et al., 2012; Wempen, 2020). The major advantage of the DInSAR method compared to any other interferometrical techniques lies in the actual results, which represent a continuous surface, unlike in the other techniques, where the resulted maps contain only point clouds, making them discontinue (Oštir and Komac, 2007). The DInSAR method utilizes fewer 
computing resources and only requires two images for the processing algorithm to work. Furthermore, this technology offers qualitative information on land deformations and movements due to its reduced topographic components of the phase, which are based on an external DEM, and can be generated with even fewer SAR data acquisitions (Fiaschi et al., 2017). Temporal decorrelation becomes an important issue in DInSAR processing, as it can cause difficulties when comparing radar imagery (Oštir and Komac, 2007). This major problem can be surpassed by pairing imagery over very short periods of time and by choosing high coherence areas (urban and non-vegetated, bare areas) (Oštir and Komac, 2007; Wempen, 2020). The Sentinel-1B SAR imagery is very suitable for DInSAR processing due to its very short temporal baseline (12 days) (Pawluszek-Filipiak and Borkowski, 2020), moreover, the satellite's sensor operates on C-band, which has relatively good performance and results over builtup areas and bare/rock surfaces (snow-free) (Herrera et al., 2013).

On a national scale, in Romania, the InSAR technique is relatively new and was used to detect landslide movements in Iași (Necula et al., 2017) and also to measure the subsidence rate in Bucharest (Poncos et al., 2014; Pătrașcu et al., 2016; Armaș et al., 2016; Dănișor and Dâtcu, 2018; Gheorghe et al., 2020).

In this research, social and economic dimensions were not taken into account due to the complexity and volume of data acquisition. A particular condition (in our case, the active land deformations from the past year) was taken into consideration, which can likely describe the behaviour (predisposition) of the study area qualitatively. Therefore, we did not accentuate susceptibility frameworks in this study, because our scope is to describe and quantify further possible displacements of a geomorphological event's surrounding area by using a single preexisting condition.

Therefore, our exploratory research aims to display a potential usage of Synthetic Aperture Radar Interferometry (InSAR) and to provide an up-todate, fast and advanced methodology to investigate Cluj-Napoca city's most active land surface deformations that have occurred in the last year and were most affected by urban sprawl. Ground displacement in built-up areas can have a great impact on the development and land-planning strategies of cities, especially if they are human-induced (Armaș, 2017), therefore, our main objective is to gain a more profound knowledge of the geographical positions and velocities of the landmass displacements analysed between 2019 and 2020, using radar data. Also, by generating a predisposition map based on the modified methodologies of Gligor et al. (2012) and Ciampalini et al. (2016), we can describe how reliable an area can be for construction works. Moreover, by combining GIS with remote sensing techniques, we can delineate the neighbourhoods, within the study area, which are predisposed to land surface displacements.

\section{Study area}

Cluj-Napoca is placed in a hilly environment in the central-western part of Transylvania, over the Someșul Mic and Nadăș River valleys, at the intersection of the $46^{\circ} 46^{\prime} \mathrm{N}$ parallel with the $23^{\circ} 36^{\prime} \mathrm{E}$ meridian. In the northern part of the municipality, the Sfântu Gheorghe and Lomb Hills are situated, the western part occupies the Hoia Hill, and the southern side includes a part of the Feleacului and Gârbăului Hills (Fig. 1). In the past 30 years, the city limit has extended by $158 \%$, therefore many constructions were built on the steeper slopes of the surrounding hills with $5^{\circ}-26^{\circ}$ inclination (Fig. 2), leading to a rapid trigger of land surface deformations. As an area of interest, we have selected a part of the city, which is the most affected by urban sprawl and built-up area extension. The geographical location of the study area is shown in Fig. 1. Moreover, in the future, we intend to conduct further DInSAR studies for the remaining part of the municipality, so we can compare the displacement values of the two distinct parts of the city described above, in order to determine the behaviour of deformations on two different geological structures. This split is also a very resource-oriented method, allowing us to use less computing power to achieve the desired accuracy of the displacement values.

The study area represents the most populated and dynamic part of the city, it incorporates the most important points of interest and has a higher 
built-up rate compared to the remaining part. The territory is heavily influenced by anthropogenic and peri-urban activities, it is very dynamic in terms of buildings and road construction, land-use and landcover changes (deforested areas, pastures and orchards turned into built-up areas), determining an increase in geological and geomorphological hazards.

The description of the geological setting of the study area was compiled after Baciu and Filipescu (2002) and Poszet (2017). The geological structure of the study area includes Paleogene (Late Eocene and Early Oligocene) and Neogene (Early- and Middle-Miocene) sedimentary formations, partially covered by Quaternary (Pleistocene and Holocene) detrital deposits. Analysing the lithostratigraphic units (detailed in Fig. 3) and the geological map (Fig. 4) of the study area, it can be observed that the most predominant formations (Brebi, Moigrad and Dâncu, Coruș and Chechiș, Feleac, and Iris Formations), aside from the Dej Tuff complex consist of marls, clays, sands and sandstone, making the study area very susceptible to different mass movement/ land deformation processes.

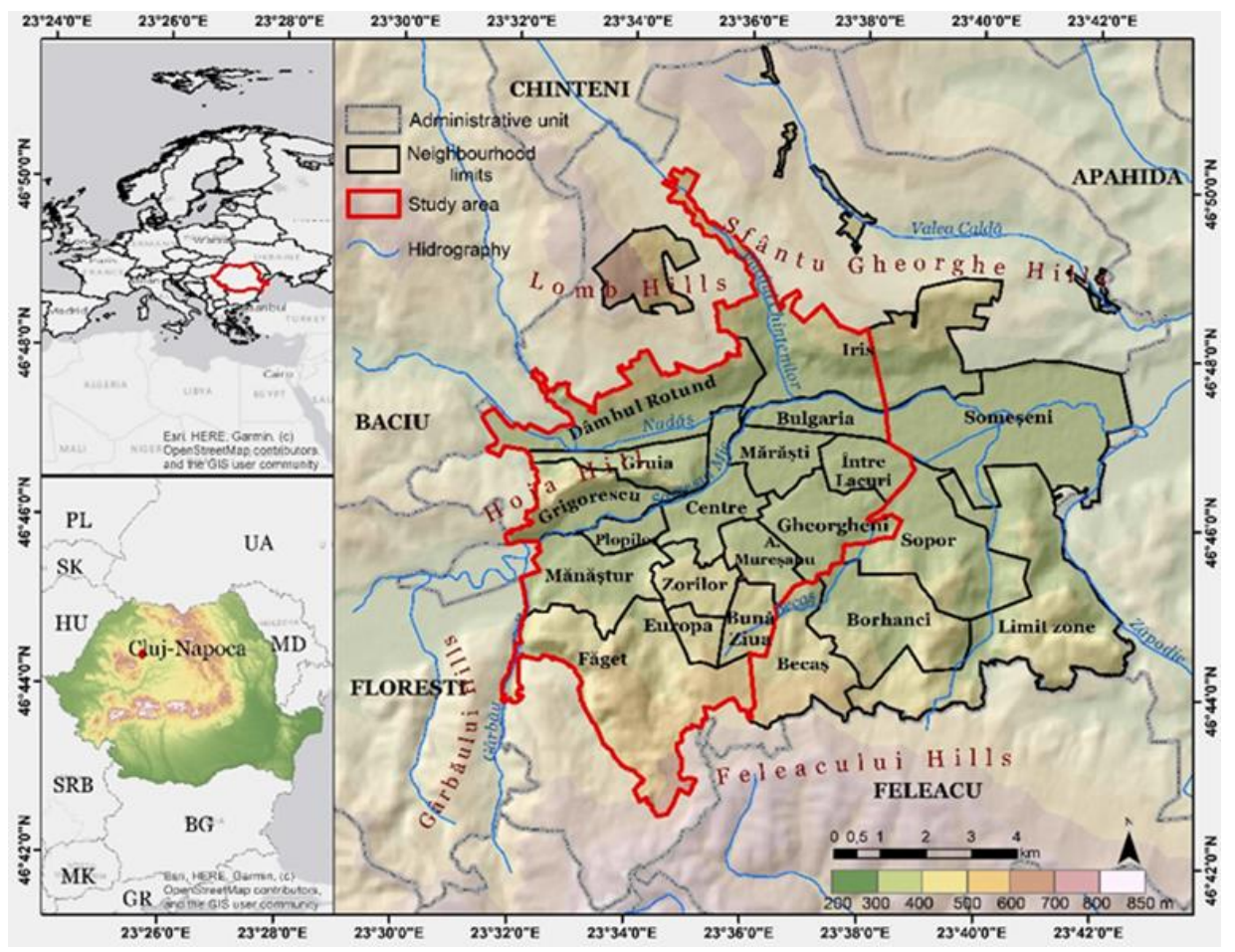

Figure 1 The geographical position of Cluj-Napoca city (in Europe and Romania) and the extension of the study area

The architecture of the strata is generally monoclinal in the study area, and features large folds to the east. Some large faults affect the general structure, the most conspicuous of them cutting the Paleogene deposits on the eastern side of Cetățuia Hill (Fig. 4).

The geomorphological structure is highly influenced by the above-described geological formations, by the periglacial conditions of the Quaternary, river erosion and anthropogenic effects (Poszet, 2017). Fluviatile and superficial deposits were formed during the Quaternary, with the seven terraces of the Someșul Mic River as the most no- ticeable elements. The Pleistocene displacements, the periodical thawing and the recent (Holocene) and Pleistocene landslides have relocated the entire mass of sediments on lower positions of the slope. In the Holocene, the intense anthropogenic activities, like deforestation, overgrazing and construction works have triggered slope failures and thus many land mass movements have been reactivated (Kerekes et al., 2018). The majority of these mass movements are landslides (both rotational and translational), soil-creeping, land subsidence (especially near the floodplain / on calcareous formations) and earth slumps (on very steep slopes). 

(Romania)

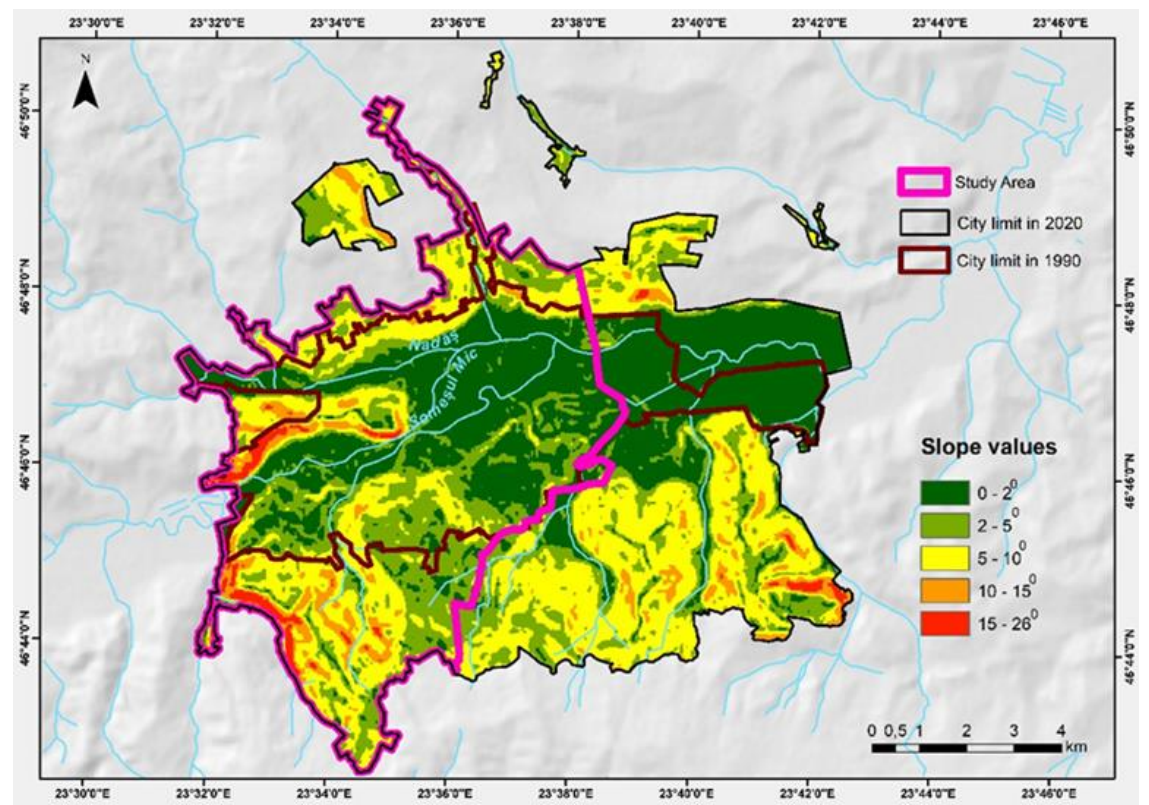

Figure 2 The city limit expansion over the past 30 years and the slope values of the city (derived from $5 \mathrm{~m}$ resolution DEM; source: digitized elevation curves from 1:5000 topographical maps)

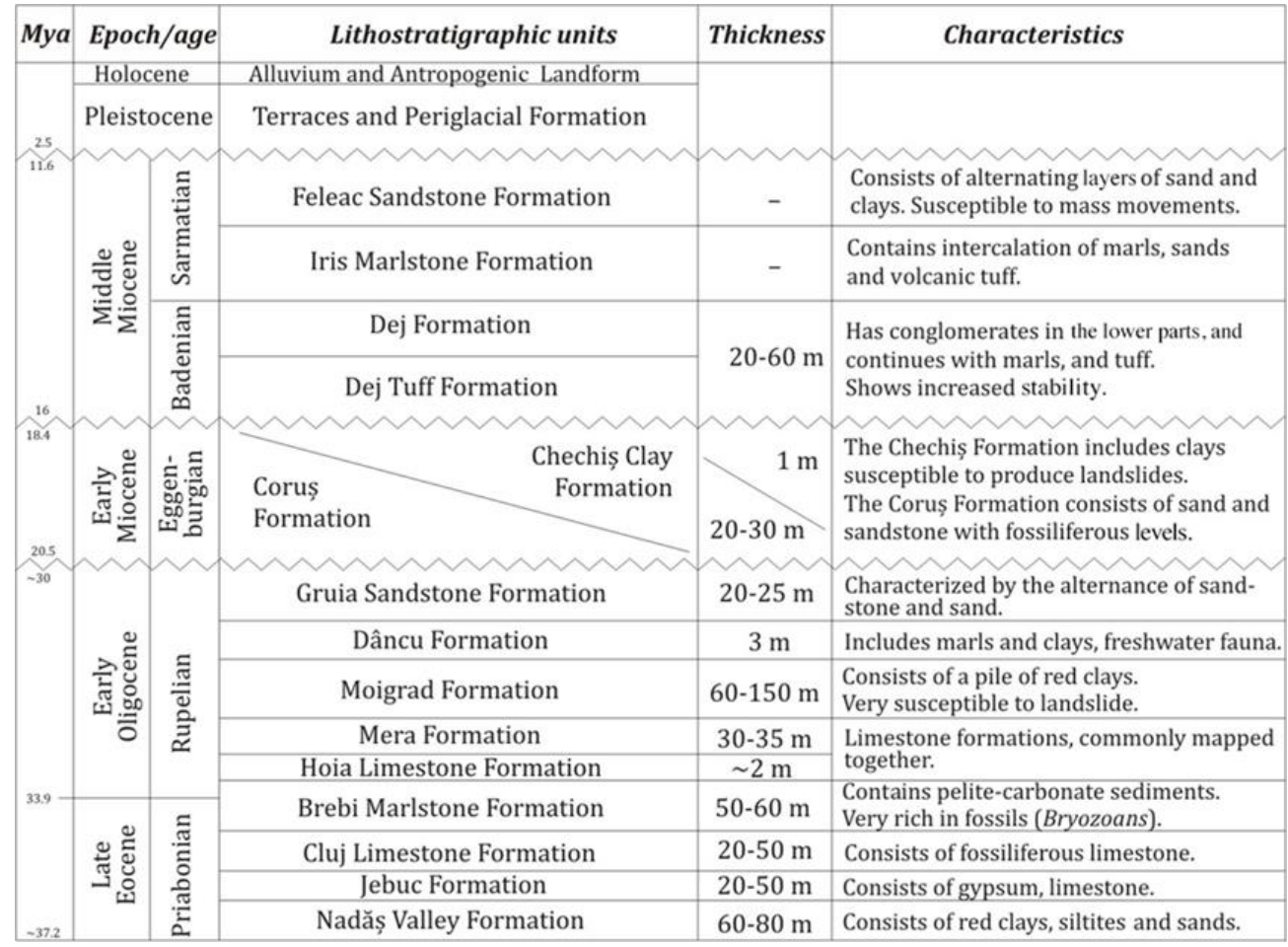

Figure 3 The lithostratigraphic units of the study area (after Poszet, 2017)

\section{Data and methods}

The approach applied in this study consists of two main procedures: the generation of the land deformation map from the interferometric products, and the delineation of the predisposed areas. In order to achieve the final maps, two specific GIS and remote sensing software products were used: SNAP 7.0 (developed by the European Spatial Agency) and ArcGIS 10.5 . 


\subsection{Datasets}

The deformation map was derived from Sentinel-1B SAR imagery, which characteristics can be seen in Table 1. The SAR imagery was acquired from the European Space Agency (ESA) and has a ground resolution of $5 \mathrm{~m}$ in the range direction and $20 \mathrm{~m}$ in the azimuth direction. In this study, we used 11 pairs of radar images, acquired between September 2019 and August 2020, with a descending orbit and vertical polarization. To reduce the spatial decorrelation, we used data with a small temporal baseline (approximately 1 -month interval between two SAR images).

In order to emphasize the extension of the urban sprawl of the area under investigation, we also used Landsat 5 TM from 1991.06.19 and Landsat 8 OLI from 2020.06.27, imagery acquired from the U.S. Geological Survey.

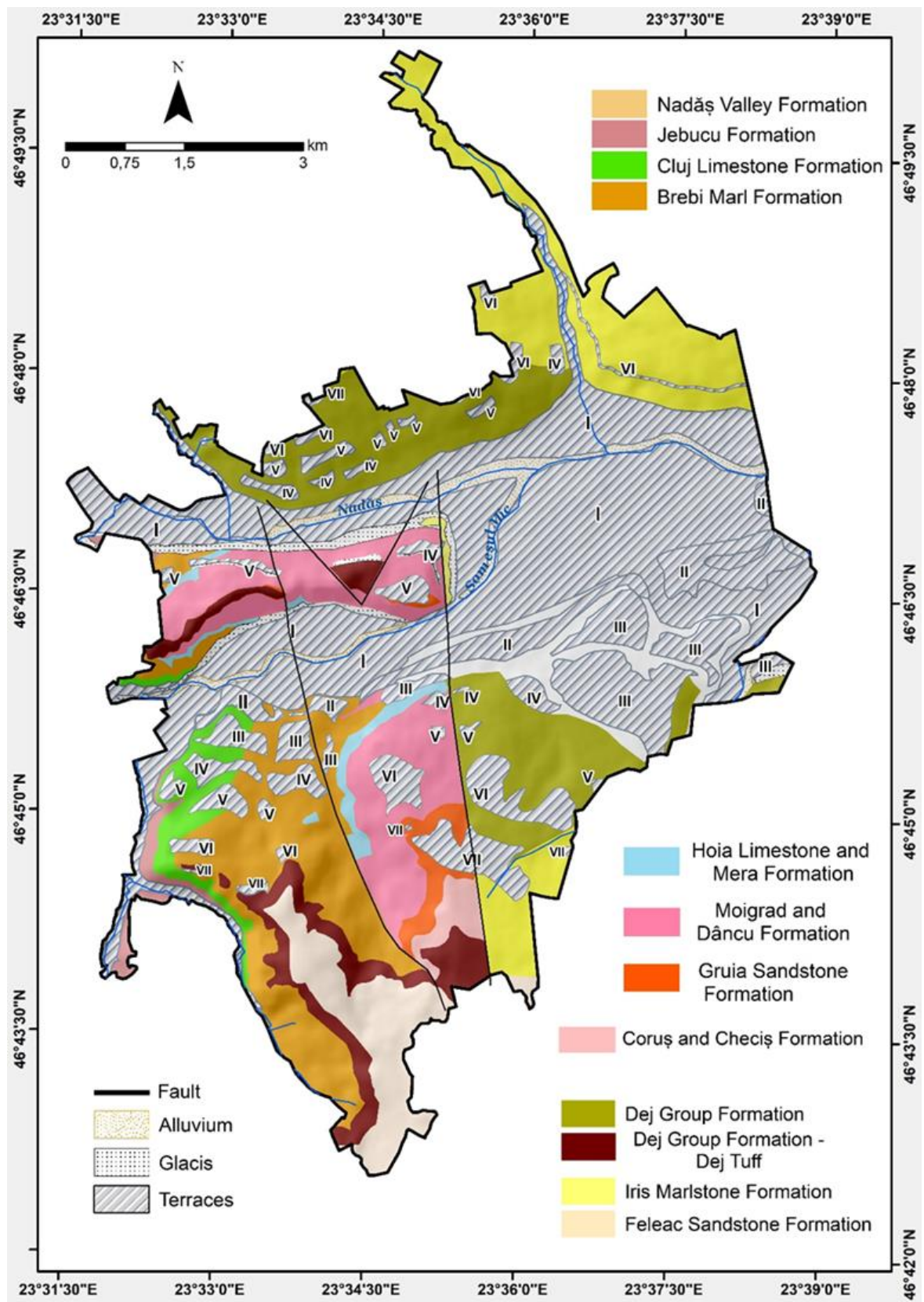

Figure 4 The geological map of the study area (after Poszet, 2017, scale 1:5000) 
Table 1 The acquired Sentinel-1B SAR imagery characteristics

\begin{tabular}{cccccc}
\hline Pairs & Date & $\begin{array}{c}\text { Elapsed time } \\
\text { (days) }\end{array}$ & Baseline $(\mathbf{m})$ & Orbits & $\begin{array}{c}\text { Average incidence } \\
\text { angle }\end{array}$ \\
\hline $\mathbf{1}$ & $2019.09 .04-2019.10 .10$ & 36 & -15.00 & $17883-18408$ & 47 \\
$\mathbf{2}$ & $2019.10 .10-2019.11 .03$ & 24 & -19.40 & $18408-18758$ & 47 \\
$\mathbf{3}$ & $2019.11 .03-2019.12 .09$ & 36 & -68.90 & $18758-19283$ & 47 \\
$\mathbf{4}$ & $2019.12 .09-2020.01 .14$ & 36 & -36.00 & $19283-19808$ & 47 \\
$\mathbf{5}$ & $2020.01 .14-2020.02 .07$ & 24 & -72.28 & $19808-20158$ & 47 \\
$\mathbf{6}$ & $2020.02 .07-2020.03 .02$ & 24 & -187.21 & $20158-20508$ & 47 \\
$\mathbf{7}$ & $2020.03 .02-2020.04 .07$ & 36 & -160.12 & $20508-21033$ & 47 \\
$\mathbf{8}$ & $2020.04 .07-2020.05 .01$ & 24 & -130.54 & $21033-21383$ & 47 \\
$\mathbf{9}$ & $2020.05 .01-2020.06 .18$ & 48 & 54.06 & $21383-22083$ & 47 \\
$\mathbf{1 0}$ & $2020.06 .18-2020.07 .24$ & 36 & -3.67 & $22083-22608$ & 47 \\
$\mathbf{1 1}$ & $2020.07 .24-2020.08 .29$ & 36 & 21.18 & $22608-23133$ & 47 \\
\hline
\end{tabular}

\subsection{Methods}

In this study, we chose to render the displacement map using DInSAR methodology owing the fact that the PSI technique utilizes advanced computer resources, thus becoming time-inefficient. Moreover, using the Differential Interferometry SAR technique, the resulted velocity map represents a continuous, grid-based surface, whereas the output of the PSI model is vector-based and shows discontinuous data. Therefore, by using the DInSAR method, data interpretation and spatial analysis becomes easier. The DInSAR methodology is suitable for dynamic process analysis (Ullo et al., 2019). It is based on measuring the phase shift between two successive SAR images which must be acquired (in different time periods) over the same location and their orbital parameters are well known (Oštir and Komac, 2007; Fiaschi et al., 2017). By processing these two SAR images, an interferometric phase (phase difference between the two images) is obtained, which is used to calculate the relative ground deformations (Fárová et al, 2019; Fiaschi et al., 2017). The interferometric phase can be described with the following formula (Hanssen, 2001, Ullo et al., 2019):

$\Delta \phi=\Delta \phi$ flat $+\Delta \phi$ height $+\Delta \phi$ displacement + $\Delta \phi$ atmosphere $+\Delta \phi$ noise

where $\Delta \phi$ flat represents the phase of the flat-Earth, $\Delta \phi$ height means the residual topography induced phase, $\Delta \phi$ displacement stands for the displacement measured along LOS (line of sight - contains both vertical and horizontal displacement) between the observations, $\Delta$ patmosphere shows the delay of the electromagnetic waves caused by the changes in the ionospheric dielectric constant and $\Delta \phi$ noise stands for the decorrelations/residual noise.

The DInSAR method aims to eliminate all the phase contributions mentioned above, aside from displacement, therefore obtaining the relative ground deformations (Hanssen, 2001).

Data processing was carried out based on the classical methodology described by Ullo et al., 2019, as follows:

- Image Coregistration: the SAR images must be aligned to be able to be compared pixel-bypixel for difference detection.

- Interferogram Formation: the flat-Earth phase is removed by using orbital information and metadata.

- Multilooking and Phase Filtering (Goldstein filtering): these steps are used to remove speckle noise and it also enhances the accuracy in the course of the unwrapping step.

- Topographic phase removal: using an a priori available DEM, the topographic and geometric phase contribution can be eliminated.

- Phase Unwrapping: this step is carried out using the SNAPHU plugin; the algorithm is developed by Stanford University. Phase unwrapping resolves the ambiguity of interferometric phase (corresponding to multiples of $|2 \pi|)$, therefore it is replacing the rectified multiples of $|2 \pi|$ of each pixel. After these steps, the LOS displacements are obtained.

This methodology was applied on the above mentioned 11 pairs of SAR images (consecutive 
DInSAR) and they were all summed up in order to generate the final displacement map.

After obtaining the deformation map, we applied the approaches used by Gligor et al. (2012) and Ciampalini et al. (2016) in order to estimate, for the past year, the areas with great predisposition rates to land surface deformations. In addition to these methodologies, we introduced a change in the approximation of the predisposition rates by using weighted area values, therefore we associated the 5 LOS land displacement classes (obtained by natural break distribution) with the following weights: $0-(0 \mathrm{~m} \div 0.01 \mathrm{~m})$; $1-(-0.03 \mathrm{~m} \div 0 \mathrm{~m}), 2-$ $(-0.05 \mathrm{~m} \div-0.03 \mathrm{~m})$ and $(0.01 \mathrm{~m} \div 0.05 \mathrm{~m}), 3-$ $(0.05 \mathrm{~m} \div 0.10 \mathrm{~m})$ and $(-0.07 \mathrm{~m} \div-0.05 \mathrm{~m})$, where 0 means relatively stable surface, 1 stands for slow deformations, 2 represents medium speed mass movements and 3 stands for relatively high velocity land deformations. In order to estimate the predisposition and the sensitivity to further displacements of a geomorphological event's surrounding area, we divided the deformation map into square cells, each containing areas with different displacements and weight values. The average area weighted values formula was used in order to estimate the predisposition for each cell:

$P=\sum_{i=1}^{n}\left(A_{d i} / A_{c}\right) * W_{i}$

where, $\mathrm{P}$ represents the predisposition estimation value of a cell, Adi represents an area from a land displacement class, Ac is equal to the cell area, Wi means the weight of the respective land displacement class and $\mathrm{n}$ is the number of displacement areas within the cell. The results are between 0 and 3 , representing the same deformation scales presented above.

To obtain the best fit, we tested the abovementioned approach on different cell sizes, on 100 $\times 100 \mathrm{~m}$ and $200 \times 200 \mathrm{~m}$, and we were able to establish different technical purposes for each scale.

The urban sprawl is an important factor which influences the land deformation; therefore, the expansion of the investigated area was emphasized using the BU (Built-up) Index based on Landsat im- agery. This index can be calculated with the following formula (Chunyang et al., 2010):

$B U I=N D B I-N D V I$

where,

NDBI (Normalized Difference Building Index) = Near Infrared band - Shortwave Infrared band

Near Infrared band + Shortwave Infrared band

NDVI (Normalized Difference Vegetation Index) = Near Infrared band - Red band

Near Infrared band+Red band

The resulted map helped us to identify different expansion tendencies and by crossing it with the predisposition estimation, we were able to calculate the percentage of the predisposed areas.

\subsection{Validation}

After generating the final predisposition map, the next step is to evaluate our estimates. Field data and measurements are not available due to the fact that many terrain deformations occurred on private properties or on inaccessible areas, therefore, we have used the field validation method.

\section{Results and discussion}

By using the consecutive DInSAR method on all the 11 pairs of SAR imagery, the perpendicular and temporal baseline values remained low, therefore avoiding temporal and spatial decorrelation. Due to this methodology, the final displacement (deformation) map (Fig. 5) is capable of showing small, millimetric deformations. The resulted map suggests that high displacement values (which highlight the magnitude of the phenomena) appear near the steeper slopes, whereas low LOS values appear on the floodplain and terraces of the Someșul Mic River, confirming that the stable part of the city is represented by the before mentioned areas. In order to understand the distribution of high LOS velocity values, the geology of the territory must be analysed together with the complex urbanisation processes. 


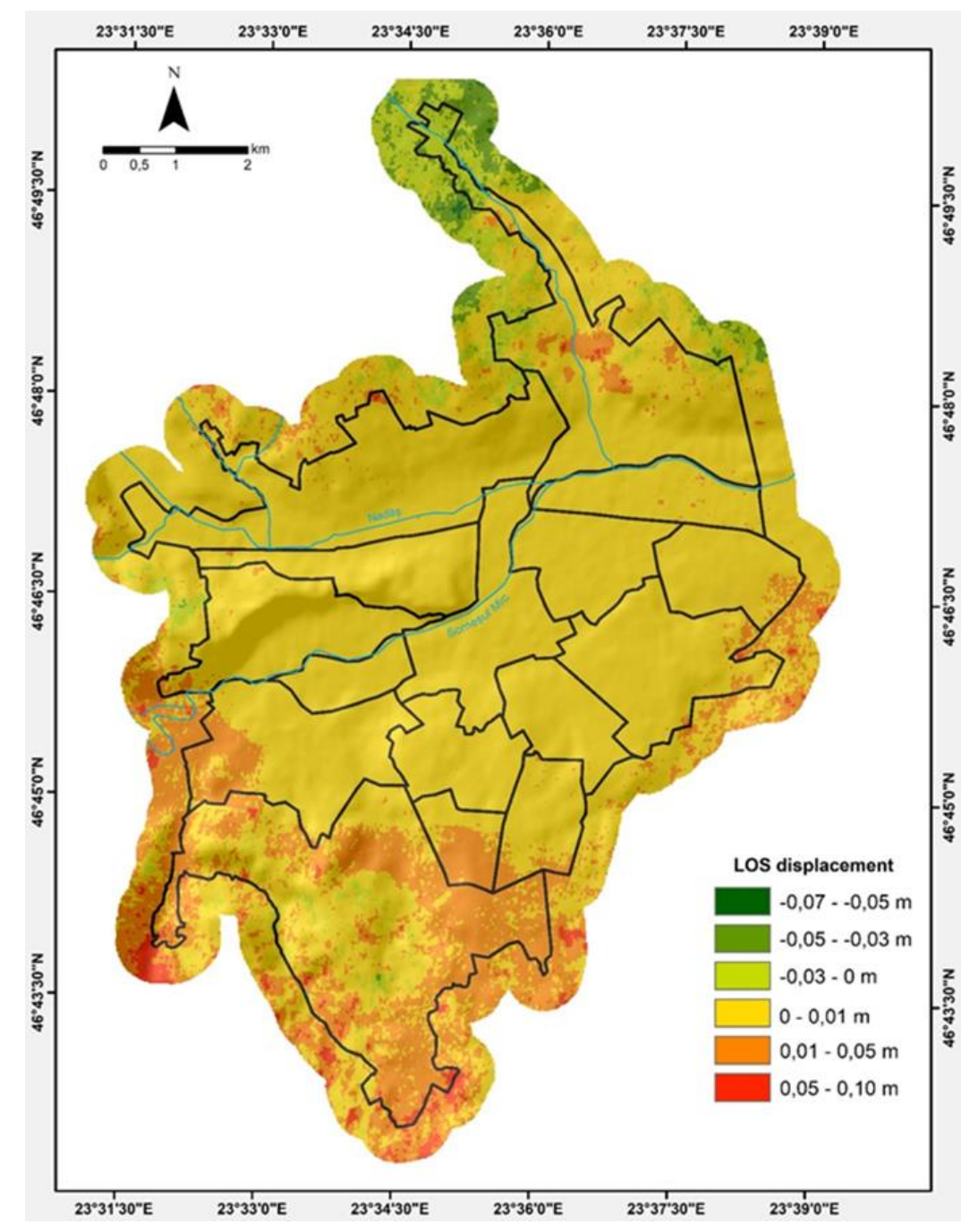

Figure 5 The deformation map of the study area based on DInSAR measurement

The urban sprawl phenomenon of the study area can be investigated by looking over the BU Index map (Fig. 6), therefore observing that over the last 30 years the built-up area has increased by approximately $32 \%$. Moreover, this expansion mainly occurs in the northern (Lomb Hills), western (Hoia Hill), and southern (Feleacului Hills, Făget, Bună Ziua, Europa) parts of the city, towards areas with steeper slopes, where new constructions have been built, and the LOS values are very high $(-0.07 \mathrm{~m}$ and $0.10 \mathrm{~m}$ ). Moreover, these slopes are characterized by sandy-clayey formations. Thus, besides the geological and geomorphological setting, we deduced that the land deformation pattern from the last year is highly influenced by anthropogenic factors, hence the city's built-up area tendency and expansion becomes compromised.

The aim of the predisposition map, which is generated by using the LOS velocity values, is to gain a clearer and more qualitative knowledge of the pattern and concentration of land deformations. We rendered two different predisposition maps on two different scales: $100 \times 100 \mathrm{~m}$ and $200 \times 200 \mathrm{~m}$, respectively (Fig. 7). We chose these two values because they represent an average area of construction. By comparing these two maps, it can be observed that the further the scale is increased, the more the cell values are being merged to the neighbouring ones, often changing their weight towards lower values. Based on this remark, we concluded that the $200 \times 200 \mathrm{~m}$ map offers an overall 
view of the predisposition of the study area, whereas the $100 \times 100 \mathrm{~m}$ becomes more precise for technical works. It is very important to study the surroundings of a mass movement because it can be a potential disruption factor to an even bigger scale and area than itself, if the slope stability is damaged. The generated predisposition maps must become reliable, therefore field validation activity was per- formed based on the methodology described by Righini et al. (2012). During this process, the maps described above were compared to the actual field conditions. Deteriorated buildings, damaged roads and landscapes represented hard evidence of land surface deformations in correspondence to the highest values of the predisposition map.

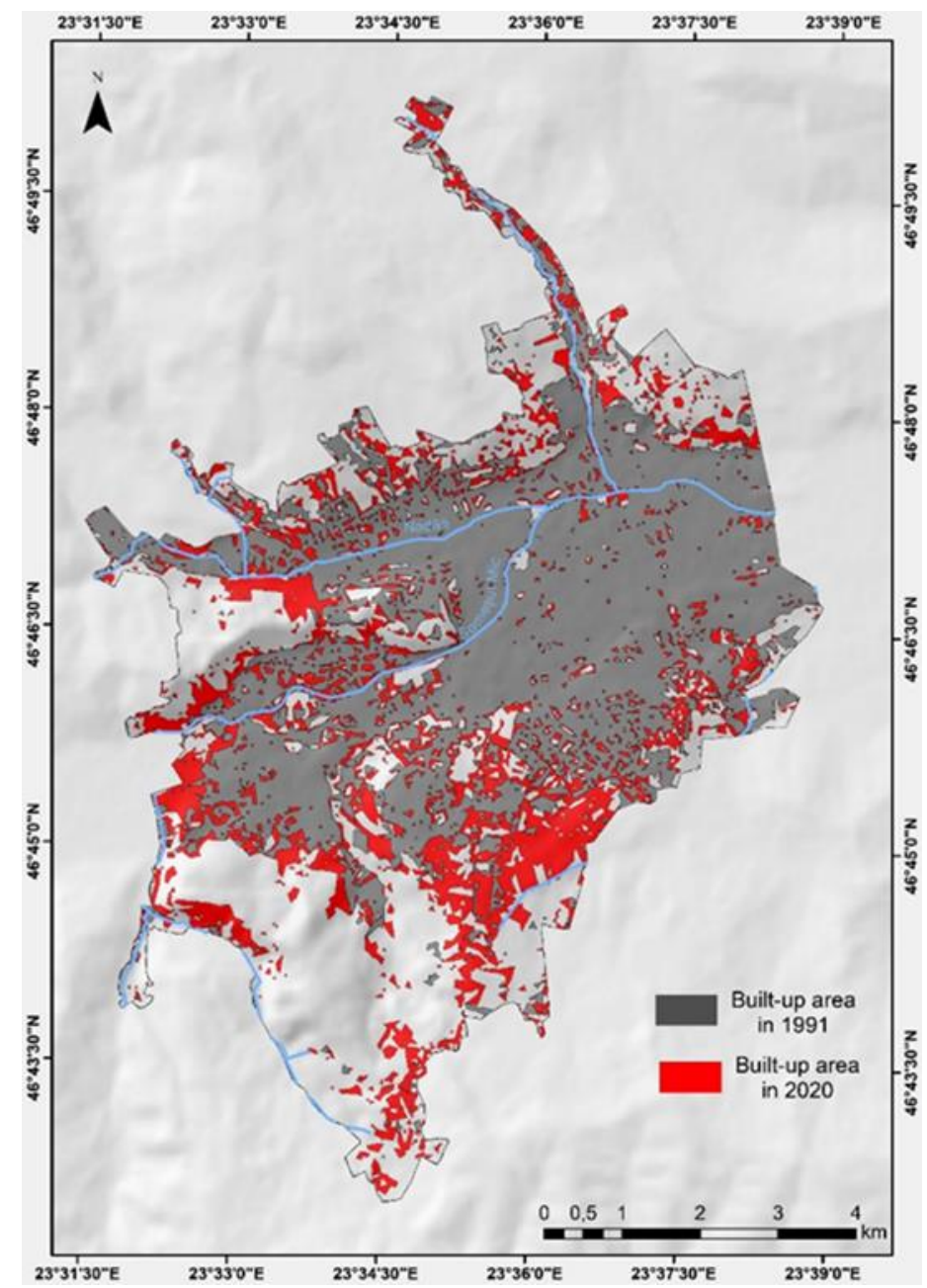

Figure 6 The built-up area evolution of the study area based on the BU Index

During the field survey, we observed that the southern, western and northern part of the study area is affected by landslides, soil-creeping and earth-slumps which correspond with the very high predisposition values of the map. As examples, a classical issue of mass displacement can be observed on Dragalina Str., which is located on Cetățuia-Hoia Hill (Fig. 8). A continuous 10-year movement of a landslide up to present, caused by land cover change and construction works can be clearly observed. The mentioned location is very unsafe for construction and the reactivation of the landslide becomes a continuous and commonly known issue. A similar reactivation example can be seen on Tăietura Turcului Str. (Cetățuia-Hoia Hill) caused by the lack of terrain stability, but also influenced by excavations, vibrations and construction works (Fig. 9). Attempts to mitigate the reactivation of the mass movement have also been done, but, unfortunately, the mesh / material that was de- 
signed to hold the terrain is in a constant state of degradation, presenting important risk of collapse. Severe road and construction damages appeared in multiple locations of Cluj-Napoca. An example can be seen on Fig. 10 where Uliului Str. (Grigorescu neighbourhood) was reinforced several times, but due to the local particular conditions, it is still under risk of sliding. Also, in the same area, many cracked houses were stabilized with alternative, improvised

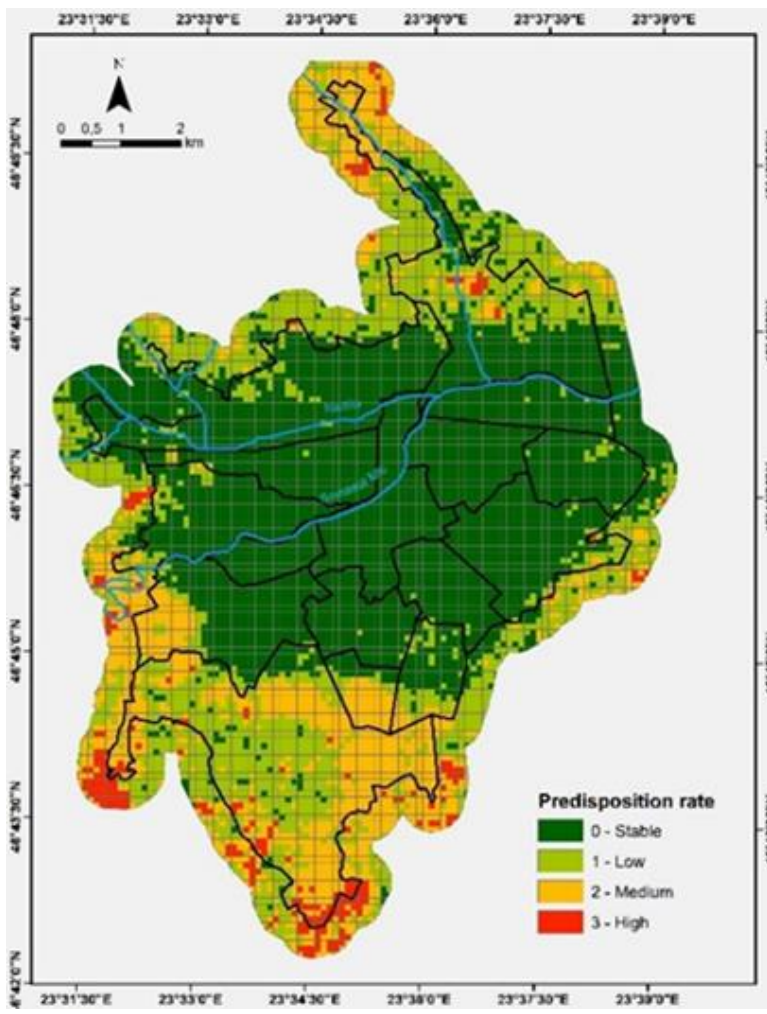

methods, like iron fences or concrete structures (Fig. 11), but unfortunately, new fractures still appear every year.

Therefore, throughout the field validation, we could observe a prominent correspondence between high terrain deformation predisposition values and the cracks on the buildings and roads, which indicates a very good reliability of the generated map.

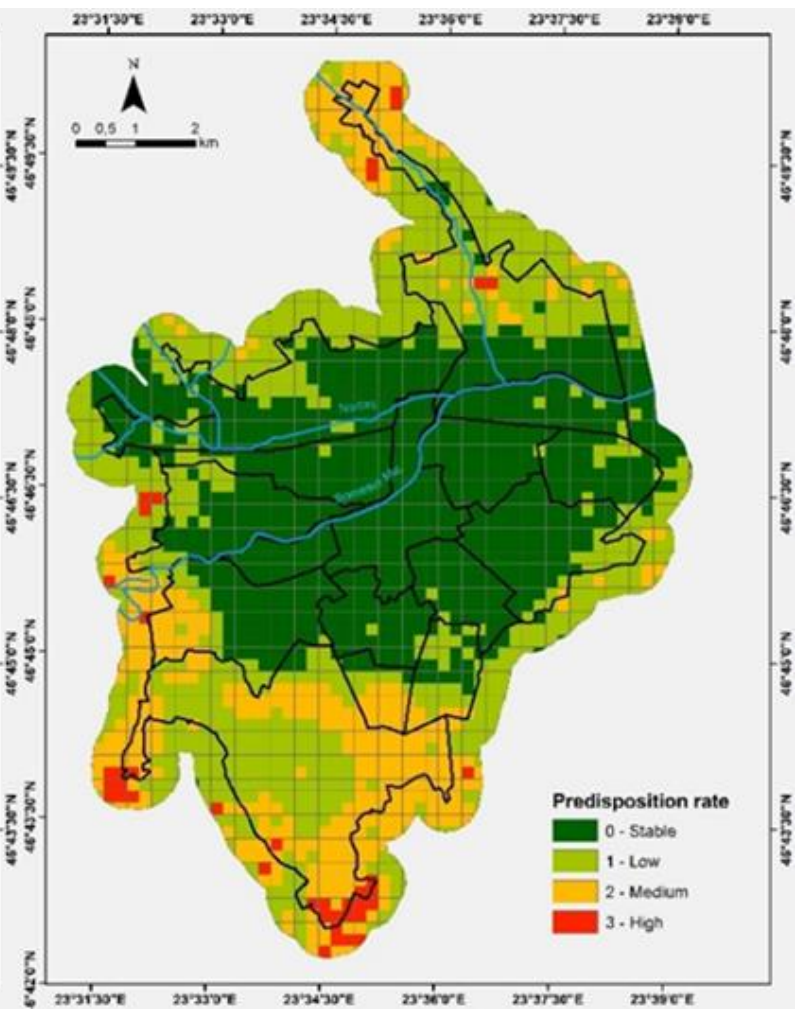

Figure 7 The study area's predisposition map on different scales (Left: $100 \times 100$ m; Right: $200 \times 200$ m)
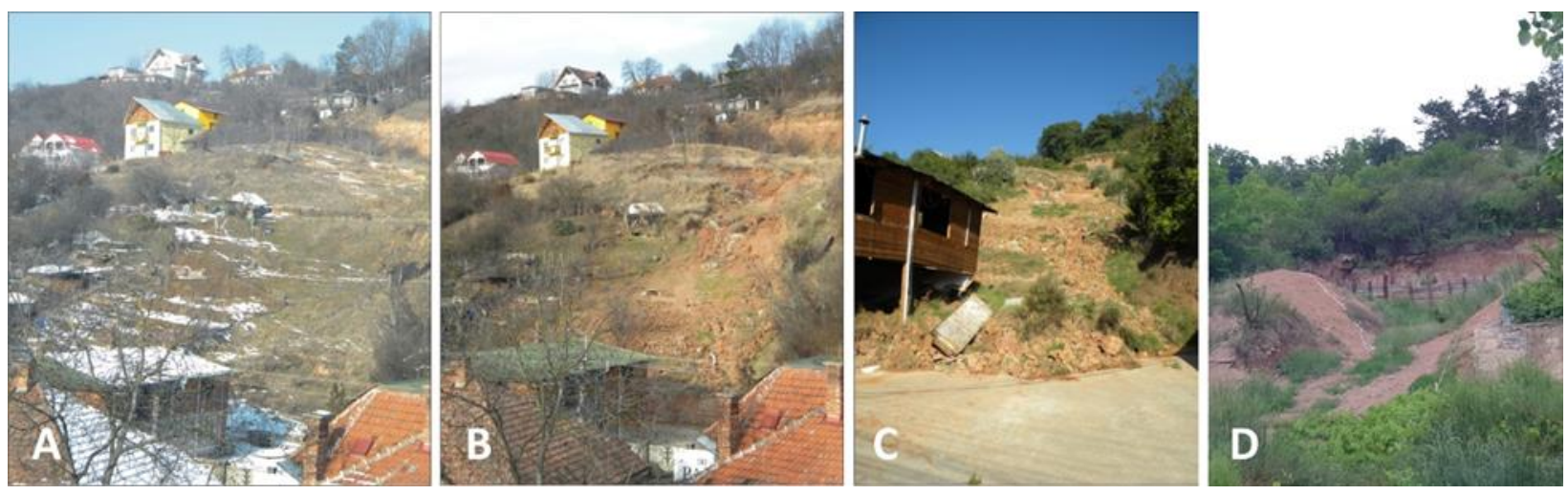

Figure 8 The reactivation of mass movements on Dragalina Str., Grigorescu neighbourhood (A: the area under dry conditions; $\mathrm{B}$ : mass movement reactivation due to constructions and high water content in soil; $C$ and $D$ : the continuous mass movement) (source of Fig. 8A and 8C: Poszet, 2017) 

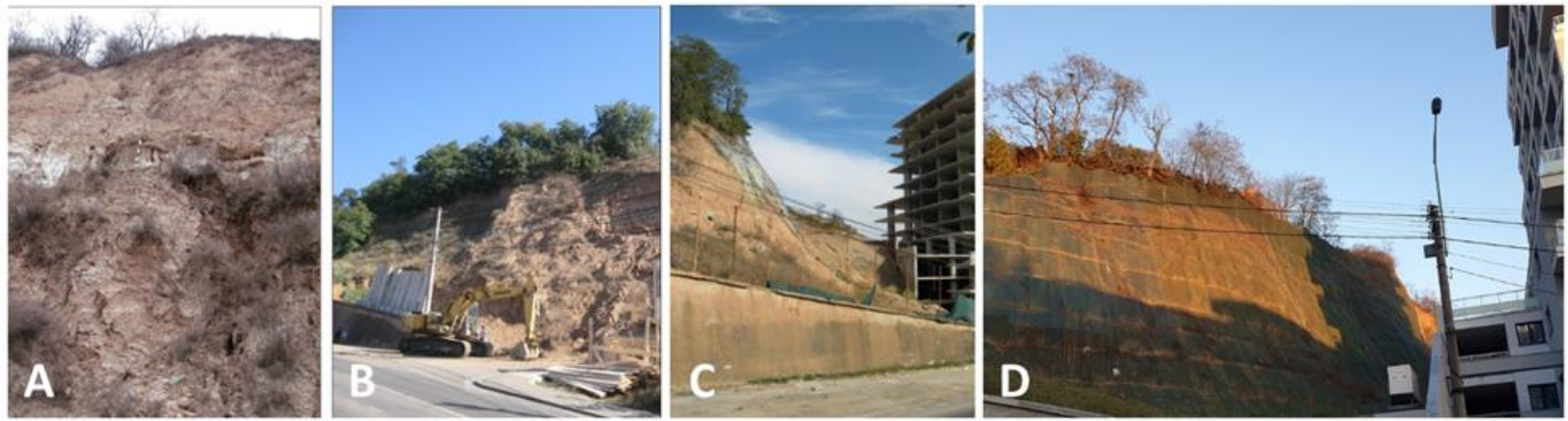

Figure 9 Human induced land deformation on Tăietura Turcului (Hoia Hill), between Grigorescu and Dâmbul Rotund neighbourhoods (A: slope before excavations; $B$ : the excavation process has disrupted the slope stability; $C$ : concrete structures have been built in order to block the mass movements; $D$ : the material that was designed to hold the terrain is degrading)

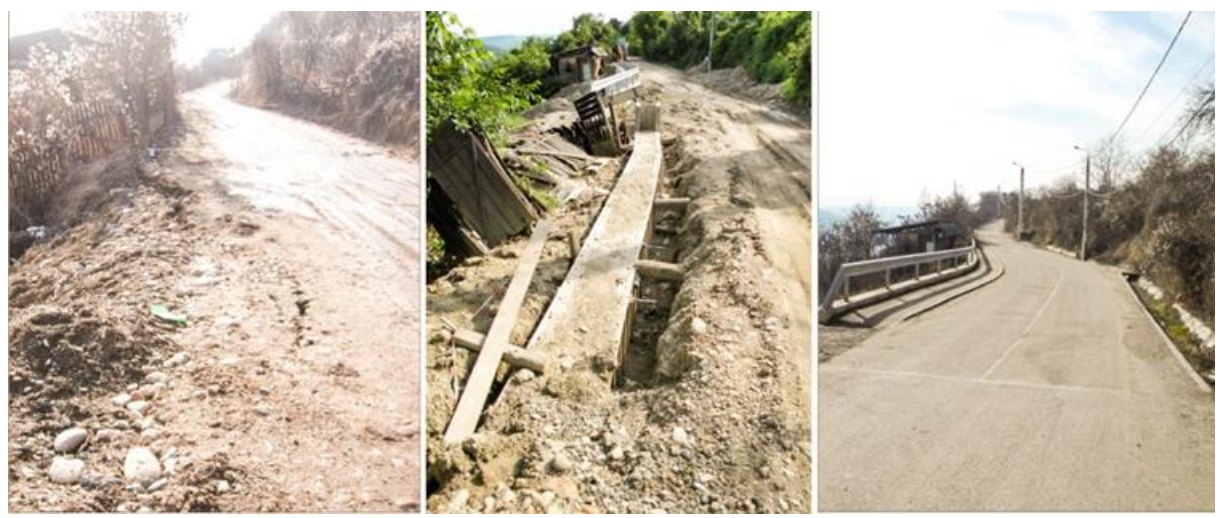

Figure 10 The restoration of Uliului Str., Grigorescu neighbourhood (Left and middle: large fractures on the street; Right: the consolidated road which is still under risk of sliding)

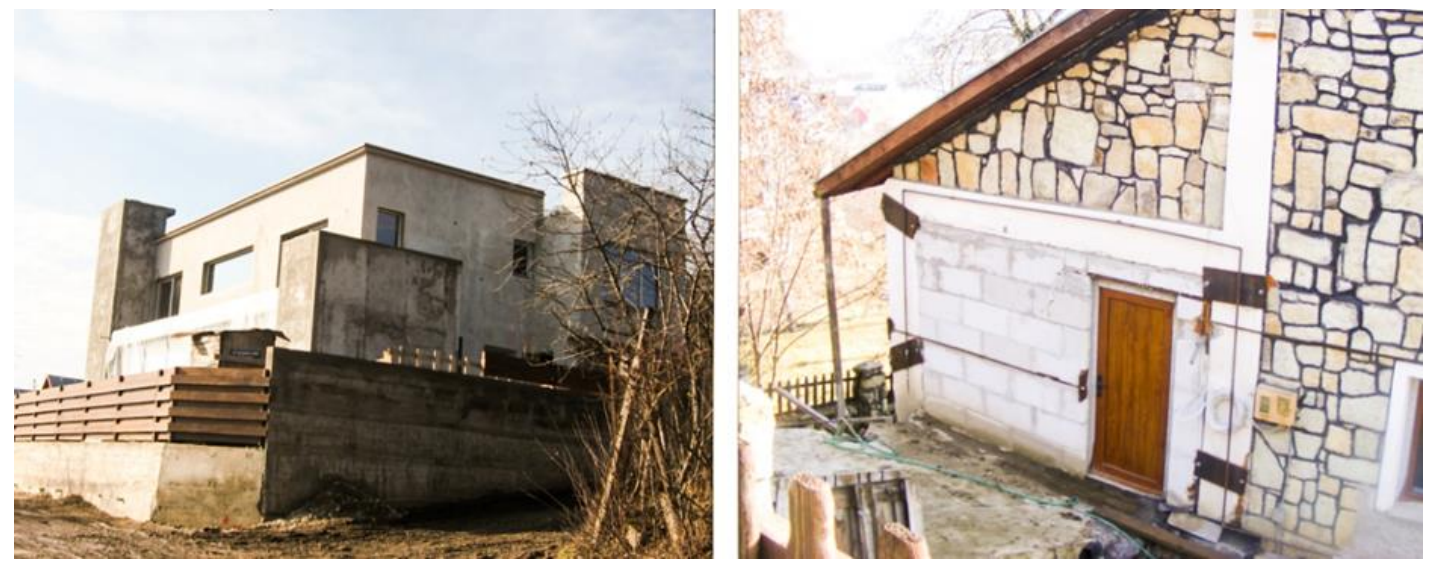

Figure 11 Attempts to repair cracked buildings (Left: alternative concrete structures used to stabilize the building; Right: improvised methods used to hold a house together)

After the validation process, some calculations based upon the $100 \times 100 \mathrm{~m}$ map were rendered. By crossing the predisposition map with the total built-up area, we concluded that $82.42 \%$ of the buildings are constructed on safe areas, but $2.15 \%$ of the remaining buildings are characterized by high, $7.95 \%$ by moderate and $7.48 \%$ by low predisposition rates. With the same methodology, we could calculate the percentual contribution of each predisposition class for each neighbourhood, as shown in Table 2. 
Investigating land surface deformation using InSAR and GIS techniques in Cluj-Napoca city's most affected sector by urban sprawl (Romania)

Table 2 Percentual contribution of each displacement class

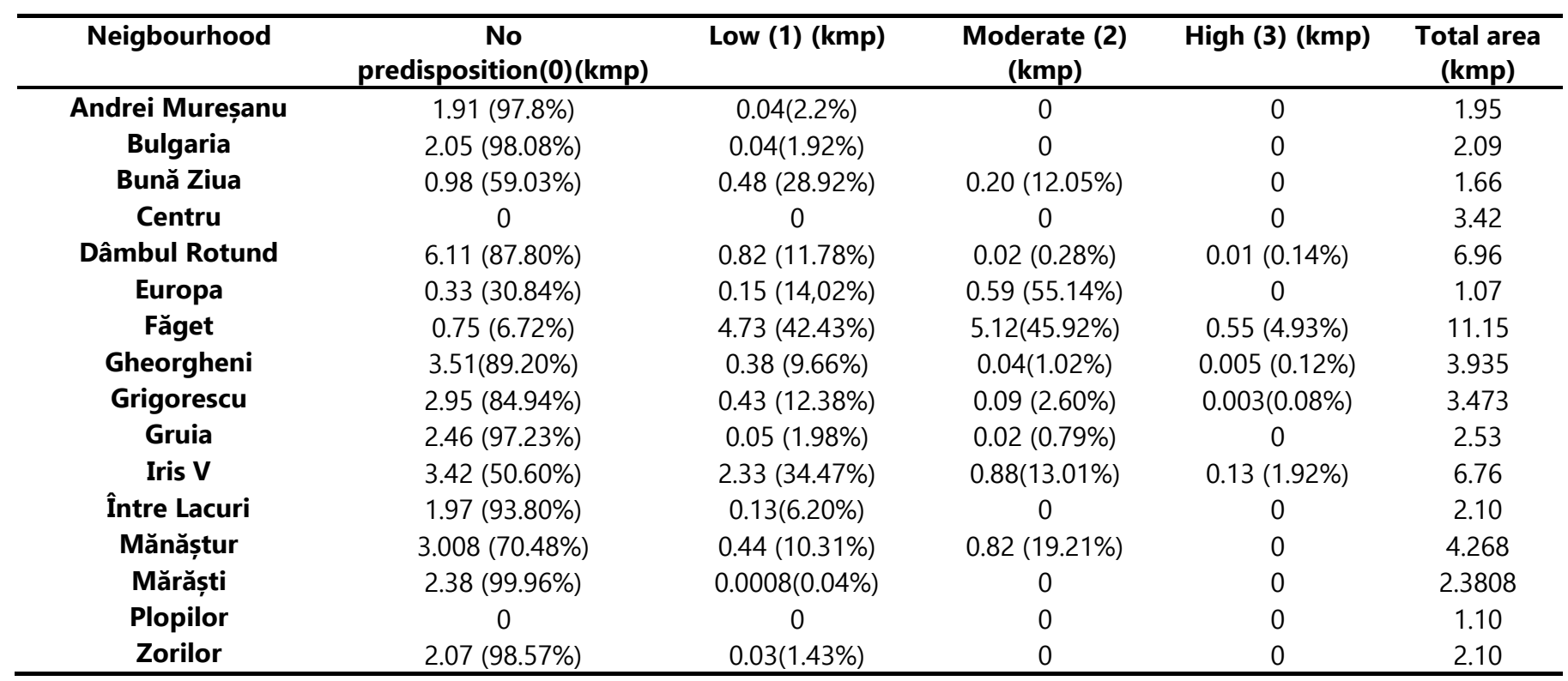

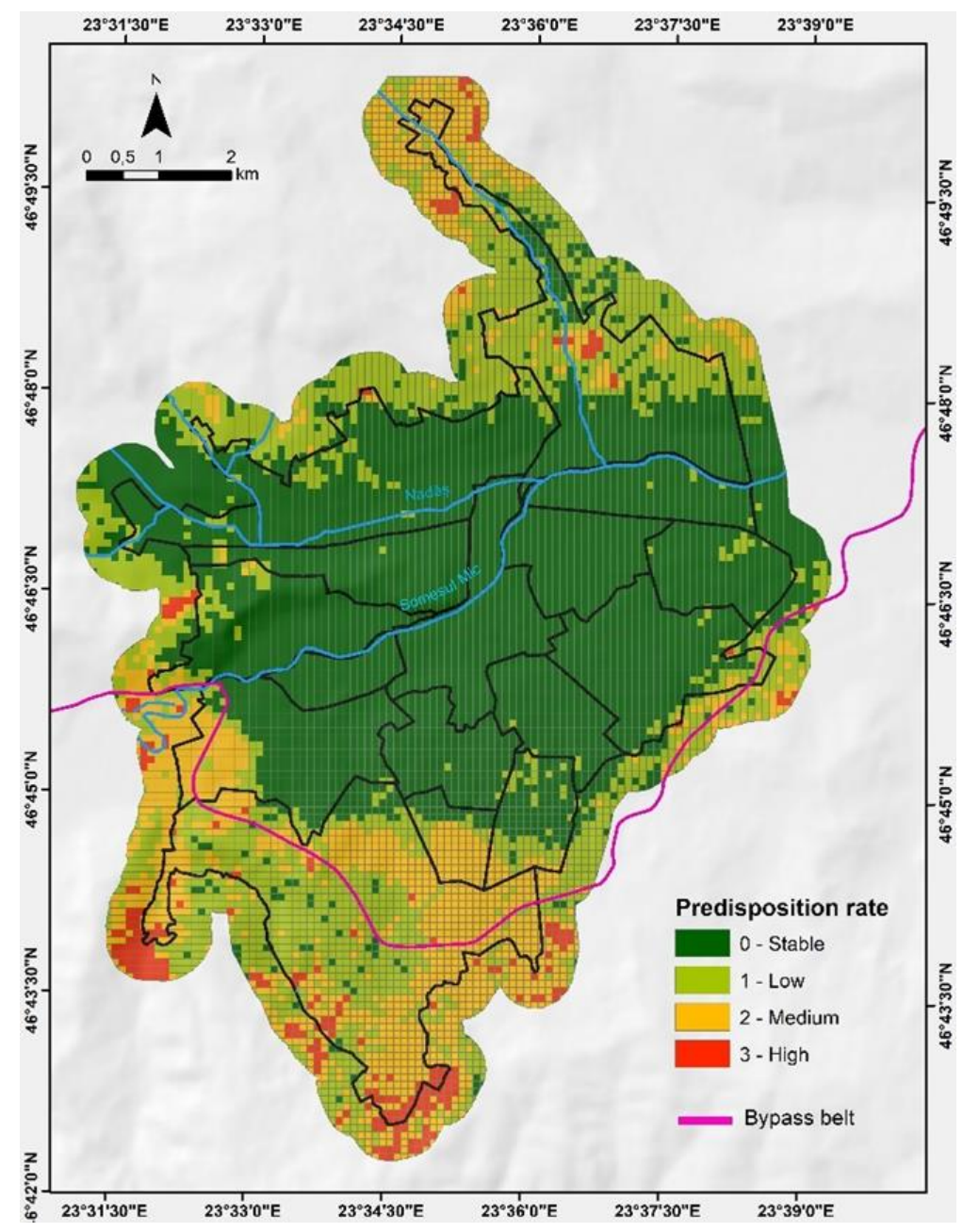

Figure 12 The path of the city's future bypass belt 
In order to determine a predisposition ranking between the neighbourhoods, we calculated a weighted average from each neighbourhood's percentage contribution (the weights and the percentage contribution can be seen in Table 2). The results indicate that the most stable parts of the city are the Centre and Plopilor neighbourhood. This can be explained by the fact that these two areas are almost entirely built on the lower terraces and the floodplain of Someșul Mic River. The moderately predisposed areas are the following: Mărăști, Zorilor, Gruia, Andrei Mureșanu, Bulgaria, Gheorgheni, Grigorescu, Între Lacuri. This sequence is relatively correct, a significant part of these territories was built on terraces, but the remaining parts of them are characterized by steeper slopes, as for example Zorilor, Gruia and Grigorescu neighbourhoods. Între Lacuri and Gheorgheni neighbourhoods show land deformations near some lakes. Also, the Eastern part of the Gheorgheni neighbourhood is affected by new construction works, which explains the presence of the sensitive areas. The most predisposed neighbourhoods, Dâmbul Rotund, Bună Ziua, Europa, Mănăștur, West Iris and Făget are showing very steep slopes, intensive anthropogenic influences and land-use change. The geological constitution of these terrains, mainly rep-

\section{Conclusions}

The InSAR technique represents a useful method to measure terrain deformations, with millimetric accuracy and also presents a wide range of applicability in different domains, like engineering and urban planning.

In this study, the DInSAR model was applied on 11 pairs of SAR images to identify and map the land surface displacements which occurred in the last year in the urban and peri-urban area of Cluj-Napoca. The unorganized expansion of a city caused important changes in the landscape, leading to numerous mass movements, mainly caused by construction works, excavations, vibrations and landuse and cover change. By using this consecutive Differential Interferometry SAR method, we avoided decorrelation and became capable to reveal small movements that cannot be observed by simple observation. The DInSAR is a cost-effective method resented by an alternation of sands, marls, and clays, also increases the predisposition to mass movements. Therefore, a detailed analysis of the geological structure, combined with the geomorphological features is important in understanding the reliability of an area for construction works in order to propose appropriate measures to avoid land surface deformations and their negative effects.

Due to the particular geologic and geomorphic features of the city of Cluj-Napoca, it is more and more difficult to find convenient locations and safe areas to build on. Very often, new major infrastructure projects need to cross zones predisposed to mass movements. One example is the new bypass belt project (Fig.12), which is meant to solve the road traffic problem within the urban area, and to ease the access to different parts of the city (PCJ, 2019). This is a technical and land planning strategy example in which our estimation map can be applied. According to our interpretation, the predisposition of this road to mass movements will be high for $0.42 \%$ of the road length, moderate for $39.89 \%$, low on $51.17 \%$, and $8.52 \%$ will be constructed on stable areas. Therefore, special technical measures should be taken in difficult sections of the route, to avoid failure.

which can yield important spatial and temporal information about the pattern of land deformations. Moreover, the resulted displacement map showed a continuous surface, therefore data interpretation and spatial analysis became easier.

Based upon an a priori knowledge of the study area, our generated predisposition map presents a good approximation and shows that due to the anthropogenic activities and geological characteristics, steeper slopes become more predisposed and have higher LOS rates $(-0.07 \mathrm{~m}$ and $0.10 \mathrm{~m})$ than the plane surfaces. The approach also determines that the most predisposed neighbourhoods in ClujNapoca are: Dâmbul Rotund, Bună Ziua, Europa, Mănăștur, West Iris and Făget. Therefore, this model shows promising results in infrastructure monitoring. The methodology also becomes suitable for a constant surveillance of areas conditioned by human induced activities in order to prevent calami- 
ties. The predisposition map highlighted the importance of analysing the surrounding area of a mass movement and it can stand as an operational tool for construction and geotechnical plans.

Future monitoring of the study area becomes an important issue. Examining and detecting landuse changes and deforestation with remote sensing techniques can also reduce potential mass movements. Also, professional consolidation of the affected constructions is needed to prevent the preexisting situation from getting worse and also, overloading must be avoided not to damage the slope's stability. Local authorities should have a close collaboration with mass movement experts, geotechnical engineers, and remote sensing specialists in order to render complex and reliable feasibility assessments.

Future works will be carried out on the whole municipality of Cluj-Napoca, using a greater amount of radar satellite imagery to generate further vulnerability, risk and susceptibility maps, which can stand as a support for future disaster mitigation works.

\section{References}

Abidin HZ, Andreas H, Gumilar I, Sidiq TP, Fukuda Y. 2013. Land subsidence in coastal city of Semarang (Indonesia): characteristics, impacts and causes. Geomatics, Natural Hazards and Risk, 4(3): 226-240

Antonielli B, Monserrat O, Bonini M, Righini G, Sani F, Luzi G, Feyzullayev AA, Aliyev CS. 2014. Pre-eruptive ground deformation of Azerbaijan mud volcanoes detected through satellite radar interferometry (DInSAR). Tectonophysics, 637: 163-177

Armaș I, Gheorghe M, Lendvai AM, Dumitru PD, Bădescu O, Călin A. 2016. InSAR validation based on GNSS measurements in Bucharest. International Journal of Remote Sensing, 37(23): 5565-5580

Armaș I, Mendes D, Popa RG, Gheorghe M, Popovici D. 2017. Long-term ground deformation patterns of Bucharest using multitemporal InSAR and multivariate dynamic analyses: A possible transpressional system? Scientific Reports, 7: 43762

Baciu C, Filipescu S. 2002. Structura geologică. In: Cristea V, Baciu C, Gafta D. (eds.) Municipiul Cluj-Napoca și zona periurbană. Studii ambientale. Editura Accent, Cluj-Napoca, 25-36
Béjar-Pizarro $M$, Notti $D$, Mateos RM, Ezquerro $P$, Centolanza G, Herrera G, Bru G, Sanabria M, Solari L, Duro J, Fernández J. 2017. Mapping Vulnerable Urban Areas Affected by Slow-Moving Landslides Using Sentinel-1 InSAR Data, Remote Sens., 9(9), 876

Bianchini S, Solari L, Del Soldato M, Raspini F, Montalti R, Ciampalini A, Casagli N. 2019. Ground Subsidence Susceptibility (GSS) Mapping in Grosseto Plain (Tuscany, Italy) Based on Satellite InSAR Data Using Frequency Ratio and Fuzzy Logic. Remote Sens., 11, 2015

Calò $F$, Ardizzone $F$, Castaldo $R$, Lollino $P$, Tizzani $P$, Guzzetti F, Lanari R, Angeli MG, Pontoni F, Manunta M. 2014. Enhanced landslide investigations through advanced DInSAR techniques: The Ivancich case study, Assisi, Italy. Remote Sensing of Environment, 142: 6982

Carnec C, Massonnet D, King C. 1996. Two examples of the use of SAR interferometry on displacement fields of small spatial extent.Geophys. Res. Lett., 23(24): 3579-3582

Cascini L, Fornaro G, Peduto D. 2010. Advanced low- and full-resolution DInSAR map generation for slowmoving landslide analysis at different scales. Engineering Geology, 112(1-4): 29-42

Chen Y, Tan K, Yan S, Zhang K, Zhang H, Liu X, Li H, Sun Y. 2019. Monitoring Land Surface Displacement over Xuzhou (China) in 2015-2018 through PCA-Based Correction Applied to SAR Interferometry. Remote Sens., 11(12), 1494

Chini $M$, Albano $M$, Saroli $M$, Pulvirenti $L$, Moro $M$, Bignami C, Falcucci E, Gori S, Modoni G, Pierdicca N, Stramondo S. 2015. Coseismic Liquefaction Phenomenon Analysis by Cosmo-Skymed: 2012 Emilia (Italy) Earthquake. International Journal of Applied Earth Observation and Geoinformation, 39: 65-78

Chunyang H, Peijun S, Dingyong X, Yuanyuan Z. 2010. Improving the normalized difference built-up index to map urban built-up areas using a semiautomatic segmentation approach. Remote Sensing Letters, 1(4): 213-221

Ciampalini A, Raspini F, Lagomarsino D, Catani F, Casagli N. 2016. Landslide susceptibility map refinement using PSInSAR data. Remote Sensing of Environment, 184: 302-315

Coleman JM, Prior DB. 1988. Mass wasting on continental margins. Ann. Rev. Earth Planet. Sci., 16: 101-19

Dalla Via G, Crosetto M, Crippa B. 2012. Resolving vertical and east-west horizontal motion from differential interferometric synthetic aperture radar: the L'Aquila earthquake. J. Geophys. Res.: Solid Earth, 117(B2)

Dănișor C, Dâtcu M. 2018. Extension of PS-InSAR Approach for DEM and Linear Deformation Rates 
Estimation. Case Study of Bucharest Area. EUSAR 2018; 12th European Conference on Synthetic Aperture Radar, Aachen, Germany, 1-6

Ezquerro $P$, Del Soldato $M$, Solari L, Tomás $R$, Raspini $F$, Ceccatelli M, Fernández-Merodo JA, Casagli N, Herrera G. 2020. Vulnerability Assessment of Buildings due to Land Subsidence Using InSAR Data in the Ancient Historical City of Pistoia (Italy). Sensors, 20, 2749

Fárová K, Jelének J, Kopačková-Strnadová V, Kycl P. 2019. Comparing DInSAR and PSI Techniques Employed to Sentinel-1 Data to Monitor Highway Stability: A Case Study of a Massive Dobkovicky Landslide, Czech Republic. Remote Sensing, 11(22), 2670

Ferretti A, Prati C, Rocca F. 2001. Permanent scatterers in SAR interferometry. IEEE Trans Geosci Remot Sens, DOI: $10.1109 / 36.898661$

Fiaschi S, Tessitore S, Boni R, Martire D, Achilli V, Bogstrom S, Ibrahim A, Floris M, Meisina C, Ramondini M, Calcaterra D. 2017. From ERS-1/2 to Sentinel-1: two decades of subsidence monitored through ADInSAR techniques in the Ravenna area (Italy). GIScience \& Remote Sensing, 54 (3)

Gabriel K, Goldstein RM, Zebker HA. 1989. Mapping Small Elevation Changes over Large Areas: Differential Radar Interferometry. Journal of Geophysical Research, 94(B7): 9183-9191

Galloway DL, Hudnut KW, Ingebritsen S, Philips SP, Peltzer G, Rogez F, Rosen PA. 1998. Detection of aquifer system compaction and land subsidence using interferometric synthetic aperture radar, Antelope Valley, Mojave Desert. California Water Resour. Res., 34 (10): 2573-2585

Gheorghe M, Armaș I, Dumitru P, Călin A, Bădescu O, Necșoiu M. 2020. Monitoring subway construction using Sentinel-1 data: a case study in Bucharest. Romania. International Journal of Remote Sensing, 41(7): 2644-266

Gligor V, Bilașco Ș, Fonogea SF. 2012. Analiza morfofuncțională a teritoriului comunei Florești (Județul Cluj) și aprecierea gradului de vulnerabilitate locală la procesele geomorfologice de risc .Geographia Napocensis, VI(1): 11-20

Griffiths JS. 2018. Mass Movement. In: Bobrowsky PT, Marker B. (eds.) Encyclopedia of Engineering Geology. Encyclopedia of Earth Sciences Series, Springer, Cham.

Hanssen RF. 2001. Radar Interferometry: Data Interpretation and Error Analysis. Kluwer Academic; Springer: Dordrecht, The Netherlands, DOI: 10.1007/0306-47633-9

Heckmann T, Gegg K, Becht M. 2014. Sample size matters: investigating the effect of sample size on a logistic regression susceptibility model for debris flow. Nat. Hazards Earth Syst. Sci., 14: 259-278

Herrera G, Guiterrez F, García-Davalillo JC, Guerrero J, Notti D, Galve JP, Fernández-Merodo, JA, Cooksley G. 2013. Multi-sensor advanced DInSAR monitoring of very slow landslides: The Tena Valley case study (Central Spanish Pyrenees). Remote Sensing of Environment, 128: 31-43

Jiaxuan H, Mowen X, Atkinson PM. 2020. Dynamic susceptibility mapping of slow-moving landslides using PSInSAR. International Journal of Remote Sensing, 41(19): 7509-7529

Kerekes AH, Poszet SzL, Gál A. 2018. Landslide susceptibility assessment using the maximum entropy model in a sector of the Cluj-Napoca Municipality, Romania. Revista de Geomorfologie, 20: 130-146

Lanari R, Mora O, Manunta M, Mallorqui JJ, Berardino P, Sansosti E. 2004. A small-baseline approach for investigating deformations on full-resolution differential SAR interferograms. IEEE Transactions on Geoscience and Remote Sensing, 42(7): 1377-1386

Lauknes TR, Piyush Shanker A, Dehls JF, Henderson IHC, Larsen Y. 2010. Detailed rockslide mapping in northern Norway with small baseline and persistent scatterer interferometric SAR time series methods. Remote Sensing of Environment, 114: 2097-2109

Ma C, Cheng X, Yang Y, Zhang X, Guo Z, Zou Y. 2016. Investigation on Mining Subsidence Based on MultiTemporal InSAR and Time-Series Analysis of the Small Baseline Subset- Case Study of Working Faces 22201$1 / 2$ in Bu'ertai Mine, Shendong Coalfield, China. Remote Sens., 8(11), 951

Massonnet D, Rossi M, Carmona C, Adragna F, Peltzer G, Feigl K, Rabaute T. 1993. The displacement field of the Landers earthquake mapped by radar interferometry. Nature, 364: 138-142

Massonnet D, Briole P, Arnaud A. 1995. Deflation of Mount Etna monitored by spaceborne radar interferometry. Nature, 375: 567-570

Necula N, Niculiță M, Tessari G, Floris M. 2017. InSAR analysis of Sentinel-1 data for monitoring landslide displacement of the north-eastern Copou hillslope, Iaşi city, Romania. Proceedings SNG, DOI 10.15551/prgs.2017.85

Oštir K, Komac M. 2007. PSInSAR and DInSAR methodology comparison and their applicability in the field of surface deformations - A case of NW Slovenia. Geologija, 50(1): 77-96

Pawluszek-Filipiak K, Borkowski A. 2020. Comparison of PSI and DInSAR approach for the subsidence monitoring caused by coal mining exploitation. The International Archives of the Photogrammetry, 
Remote Sensing and Spatial Information Sciences, Volume XLIII-B3-2020, XXIV ISPRS Congress, 333-337

Pătrașcu C, Popescu AA, Dâtcu M. 2016. Comparative assessment of multi-temporal InSAR techniques for generation of displacement maps: a case study for Bucharest area. U.P.B. Sci. Bull., Series C 78(2):135-146

PCJ (Primăria Cluj-Napoca). 2019. Varianta finală de traseu V8 pentru centura metropolitană. https://primariaclujnapoca.ro/informatii-

publice/comunicate/varianta-finala-de-traseu-v8pentru-centura-metropolitana/. Accessed 10 August 2020

Peltier A, Bianchi M, Kaminski E, Komorowski JC, Rucci A, Staudacher T. 2010. PSInSAR as a new tool to monitor pre-eruptive volcano ground deformation: Validation using GPS measurements on Piton de la Fournaise. Geophys Res Lett., 37, DOI: 10.1029/2010GL043846

Poncos V, Teleaga D, Boukhemacha MA, Toma SA, Serban F. 2014. Study of urban instability phenomena in Bucharest city based on Ps-InSAR. IEEE Geoscience and Remote Sensing Symposium, Quebec City, QC, 429-432

Poszet SzL. 2017. Studiu de geomorfologie aplicată în zona urbană Cluj-Napoca, Editura Scientia, ClujNapoca.

Righini G, Pancioli V, Casagli N. 2012. Updating landslide inventory maps using Persistent Scatterer Interferometry (PSI). International Journal of Remote Sensing, 33(7): 2068-2096
Solari L, Ciampalini A, Raspini F, Bianchini S, Moretti S. 2016. PSInSAR analysis in the Pisa Urban Area (Italy): A case study of subsidence related to stratigraphical factors and urbanization. Remote Sens., 8(120)

Solari L, Barra A, Herrera G, Bianchini S, Monserrat O, Pizarro-Béjar M, Crosetto M, Sarro R, Moretti S. 2018. Fast detection of ground motions on vulnerable elements using Sentinel-1 InSAR data. Geomatics, Natural Hazards and Risk, 9(1): 152-174

Sun Q, Zhang L, Ding XL, Hu J, Li ZW, Zhu JJ. 2015. Slope deformation pripr to Zhouqu, China landslide from InSAR time series analysis. Remote Sensing of Environment, 156: 45-57

Ullo SL, Addabbo P, Di Martire D, Sica S, Fiscante N, Cicala L, Angelino CV. 2019. Application of DInSAR Technique to High Coherence Sentinel-1 Images for Dam Monitoring and Result Validation Through In Situ Measurements. IEEE Journal of Selected Topics in Applied Earth Observations and Remote Sensing, 12(3), 1939-1404

Wempen JM. 2020. Application of DInSAR for short period monitoring of initial subsidence due to longwall mining in the mountain west United States. International Journal of Mining Science and Technology, 30(1): 33-37

Zhao F, Meng X, Zhang Y, Chen G, Su X, Yue D. 2019. Landslide Susceptibility Mapping of Karakorum Highway Combined with the Application of SBASInSAR Technology. Sensors, 19(12): 2685 